\title{
HISTORICAL RETROSPECTIVES OF THE DEVELOPMENT OF NEW MODELS OF STATE POLICY IN THE FIELD OF EDUCATION: A COMPARATIVE ANALYSIS
}

\author{
Kashirsky, Sergey Nikolaevich ${ }^{1}$, Solovieva, Svetlana Rostislavovna² \\ ${ }^{1}$ Candidate of Pedagogical Sciences, Associate Professor, Voronezh State Technical University, 20- \\ Let Oktyabrya Street, 84, Voronezh, Russia, E-mail: dream-school@mail.ru \\ ${ }^{2}$ Senior Lecturer, Voronezh State Technical University, 20-Let Oktyabrya Street, 84, \\ Voronezh, Russia, E-mail: d18sveta@mail.ru
}

\begin{abstract}
The growing role of education in the modern world is explained by global trends in economic and social development, which the state should take into account when forming its educational policy, especially in the context of creating a common European educational space. Therefore, a comparative analysis of educational policy in Russia and in Western European countries is very relevant, given the processes of formation and development of educational policy in the Western European tradition, as well as the peculiarities of Russian educational policy at the present stage.
\end{abstract}

Keywords: education, experience, politics, history, society.

\section{INTRODUCTION}

Political transformations in Russia at the end of the 20th century, the transition to a market economy, and the country's accession to the Bologna Process in 2003 actualized the need to comprehend the place and role of education in both domestic and foreign policy of the state. Such a principle of Russian educational policy as the integration of the system of higher professional education of the Russian Federation into the world system while maintaining and developing the achievements and traditions of Russian higher education with the signing of the Bologna Declaration by Russia has become especially significant, since education is increasingly becoming a way of promoting the country in the globalizing highly competitive labor market and the international market for the latest technologies and is gradually becoming one of the leading elements of geopolitics and economic strategies of states. 
Thus, consideration of the historical experience and modern trends in the formation and implementation of the educational policy of states is an urgent task of modern historical knowledge. Its development in relation to the needs of domestic political and state practice makes it possible to take into account the political interests of Russia in terms of entering the common European educational space.

\section{METHODOLOGY}

The research methodology is based on the comparative method, which makes it possible to single out the general and the particular in the main trends in the formation and implementation of educational policy in Western Europe and Russia. In the process of research, such scientific methods were used as: a historical approach, which made it possible to consider the process of forming the educational policy of states in the context of general historical and general political processes in Russia and Western Europe. With the help of socio-cultural analysis, a study of the processes of forming the educational policy of states from the standpoint of cultural values and traditions was carried out. The method of content analysis made it possible to analyze a large number of international and Russian documents regulating education issues.

\section{DISCUSSION}

From the point of view of solving the problems posed in the article, works devoted to certain aspects of the relationship and interaction between the state and education as social institutions are of great interest. Among them are works by D.V. Antipenko, V. Kineleva, L.V. Usova and others. At the same time, the problem of contradictions and tendencies for further improvement of the state educational policy is not raised in these works. The works of V.I. Baydenko, A.I. Galagan, I.M. Ilyinsky highlight the internal processes and phenomena characteristic of modern educational systems, the experience of reforms in the educational sphere and national priorities for its implementation. However, the contradictions and trends in the development of these systems in the context of global changes taking place in Russia and Europe are practically not touched upon.

Another direction is the work of Russian authors A. Abramov, S. Baranov, V.I. Matvienko, A. Novikova, where the analysis of official documents in the field of educational policy is presented.

An analysis of Russian and Western European educational policy would not be deep enough without studying the range of foreign literature devoted to the problems of forming educational policy in the context of creating a common European educational space. The works of G. Curii, I. Boyet, D. Goldner, S. Hasler, P. Rond, Winnaker and others are devoted to this problem. They mainly highlight the problems of harmonizing the architecture of national educational systems at the stage of creating a single European educational space.

The analysis of scientific literature allows us to conclude that the range of problems related to the historical, philosophical, sociological aspects of educational policy has been developed in more detail. There are practically no comparative studies of the historical experience and modern practice of the formation and implementation of educational policy in Russia and the countries of Western Europe.

\section{RESULTS}

In the field of educational policy priorities for Russia and leading European countries, it is possible to identify common and special features. It is common to declare the field of education a priority at the present stage of development of society. It is obvious that in the XXI century, the country that will lead in the economic, social and other spheres will be the one that will make the primacy in educational systems and technologies the 
foundation of its growth.

In these conditions, the policy of the countries in the field of education is aimed at creating such an education system that would contribute to the maximum development of the intellectual and spiritual potential of the individual and the people as a whole.

Both in Russia and in Western Europe, the leading role of universal values and the need to respect human rights and freedoms in the field of education are recognized. It is indisputably important to take into account, protect and preserve the peculiarities of national education systems and the uniqueness of educational traditions. It is important and necessary for the countries to introduce a quality system of education in higher education institutions, which will increase the efficiency of their activities, ensure the growth of the quality of educational services, and promote the competitiveness of higher education institutions in the international arena. In addition, at the present stage, not only this is important: the quality of education is an important component of improving the quality of life. The systematic approach and consistency of educational policy is also common to the countries selected for comparative analysis.

The peculiarities and differences include the fact that the educational policy of the countries of Western Europe in general and in general is aimed at creating a competitive education system that is attractive to foreign students and contributes to the further strengthening and development of European integration. For Russia at the present stage, such a goal is not paramount. For it, it is important to overcome the socio-economic and spiritual crisis, restore the status of Russia as a great power in the field of education and science, modernize the education system while preserving its achievements, national identity and value orientations.

In the regulatory activity of the state in education, there is also a general and special thing. We refer to the general fact that the guiding and regulating activities of the state in the field of education are carried out to achieve specific strategic goals and solve problems of national or global significance. Despite the fact that the socio-cultural features of the development of the educational systems of Russia and Western European countries differed significantly, the state's attention to the problems of the development of education from ancient times to the present day is a common characteristic for Russia and Western European countries. The structure, forms and content of education changed to meet the requirements of the time and the interests of the state, the public consciousness lived views on education as a means of updating and improving life, preserving and transmitting cultural values, and the state, in turn, used education to achieve political goals: ensuring political and social stability, the development and transformation of political systems, the development of civil society institutions, ensuring national security.

The process of reforming education in Russia is associated with the emergence of Russia in the international arena as a sovereign state, in which the processes of the formation of a market economy began.

Russia's participation in the Bologna process is due to a number of factors: the strengthening of the processes of globalization in education, the emergence of market relations in the country, including in the field of education, Russia's membership in the WTO, especially participation in the General Agreement on Trade in Services (GATS).

In modern conditions, education cannot remain in a state of internal isolation and self-sufficiency. The problems of education are inherently not unique national problems and should be considered in the panEuropean context of transforming the institutional foundations of education in the context of globalization.

\section{CONCLUSION}

Both Russia and Western Europe have relied on education as a means of solving strategic problems. Therefore, the creation of a common European educational space should take place under the auspices and control of public organizations and government agencies, and be adjusted as the first real results of the transformations appear in order to exclude possible negative phenomena. The policy of states in the field of modernization of national education systems should be based on a comprehensive and complex consideration 
of the achievements, experience of both foreign educational systems, and national traditions of education. An approach to education reform based only on economic rationale is unacceptable.

In general, it can be noted that the success of the reforms of national education systems and the creation of a common educational space in Europe and Russia largely depends on the coordinated educational policy of the countries and the consistent implementation of the decisions made.

\section{REFERENCE LIST}

Abramov A.M. (2002) Russian education in the XXI century: new frontiers. Moscow University Bulletin. Ser. 20. Pedagogical education. №. 2. Pp. 12-35. (in Russ).

Ashmarov I.A. (2017) Special educational needs in a university environment. Professional orientation. №. 2. Pp. 17-19. (in Russ).

Ashmarov I.A., Bobrovnikova M.A., Volkova E.A. (2016) On state policy in the field of regional education. Region: systems, economics, management. №. 2 (33). Pp. 90-97. (in Russ).

Ashmarov I.A., Ershov B.A. (2019) The role of Russian spiritual education in the formation of culture in a secular society of the XIX - early XX centuries. Border region in historical development: partnership and cooperation. Materials of the international scientific-practical conference dedicated to the 80th anniversary of the Victory of the Soviet and Mongolian troops on the Khalkhin-Gol river. Chita: Publisher: Transbaikal State University. Pp. 50-53. (in Russ).

Ashmarov I.A., Volkova E.A., Frolova E.V. (2015) On the formation of trends in the higher education system in the framework of modern globalization processes. Modern problems of science and education. №. 11. P. 975. (in Russ).

Baranova S. (2003) Legal framework for the organization of higher education in Russia. Higher education today. № 1. Pp. 74-80. (in Russ).

Baydenko V.I. (1999) Standards in Continuing Education: Conceptual, Theoretical and Methodological Problems. M. 295 p. (in Russ).

Education development strategy: main directions. (2002) Brief Commentaries. M.: Publication of the State Duma. 63 p. (in Russ).

Ershov B., Novikov Yu.N., Voytovich D., Ermilova O., Dushkin O., Lubkin Y. (2019) Physical culture in formation of spiritual education of young people in Russia. The European Proceedings of Social \& Behavioural Sciences EpSBS. Pp. 3648-3653. (in Russ).

Ershov B.A., Nebolsin V.A., Solovieva S.R. (2020) Higher education in technical universities of Russia. 7th International conference on education and social sciences. Abstracts \& Proceedings. Pp. 55-58. (in Engl).

Ershov B.A., Perepelitsyn A., Glazkov E., Volkov I., Volkov S. (2019) Church and state in Russia: management issues. 5th International conference on advences in education and social sciences. Abstracts \& Proceedings, e-publication. Pp. 26-29. (in Engl).

Ershov B.A., Zhdanova T.A., Kashirsky S.N., Monko T. (2020) Education in the university as an important factor in the socialization of students in Russia. 6th International Conference on Advances in Education. Abstracts \& Proceedings. Pp. 517-520. (in Engl).

Galagan A.I. (2002) Integration Processes in Education: Analysis of World Trends. Social and humanitarian knowledge. №. 5. Pp. 73-85. (in Russ). 
Gorev V.N., Kudryavtsev Y.A. (2002) Education in the conditions of market relations (foreign experience). M. 125 p. (in Russ).

Granichina O. A. (2006) Quality control of the educational process in universities in Russia and abroad. SPb. 211 p. (in Russ).

Kopylova A.V. (2000) Legal support and personnel policy of educational authorities of the Russian Federation. Eagle. 205 p. (in Russ).

Kozminski A. (2003) The role of higher education in reforming society in the context of globalization: academic reliability and the desire to improve the level of universities. Higher education today. № 3. Pp. 34-38. (in Russ).

Marru A.I. (2003) History of education in antiquity. M. 310 p. (in Russ).

Milner B.Z. (2003) Knowledge Management. M. 178 p. (in Russ).

Nechaev V.Ya. (2004) Parameters of Globalization and Factors of the Bologna Process. Globalization and education. The Bologna Process. Issue 2. Pp. 10 - 21. (in Russ).

Pautova V.A. (2005) History of the formation of the German higher education system. Modernization of the national higher education system and the problems of integrating Russian universities into the world educational space. Novosibirsk. Pp. 20-22. (in Russ).

Petrov V.N. (2004) Development of teacher and student mobility in the Russian educational space as a condition for entering the Bologna process. Globalization and education. The Bologna Process. Issue 2. Pp. 142-143. (in Russ).

Sharonova S.A. (2004) The Bologna Process: Civilizational Causes. Globalization and education. The Bologna Process. Issue 2. Pp. 144-146. (in Russ).

Slyusarenko I. O., Ershov B. A. (2013) Spiritual and moral education and education in the field of global problems of modernity. In the collection: Russia and the world at a new stage of global competition. materials of the International Scientific and Practical Student Conference. Pp. 247-249. (in Russ).

Sorokin P.A. (2002) Man. Civilization. Society. M. 430 p. (in Russ). 


\title{
ИСТОРИЧЕСКИЕ РЕТРОСПЕКТИВЫ РАЗВИТИЯ НОВЫХ МОДЕЛЕЙ ГОСУДАРСТВЕННОЙ ПОЛИТИКИ В ОБЛАСТИ ОБРАЗОВАНИЯ: СРАВНИТЕЛЬНЫЙ АНАЛИЗ
}

\section{Каширский Сергей Николаевич', Соловьёва Светлана Ростиславовна²}

\author{
${ }^{1}$ Кандидат педагогических наук, доцент, Воронежский государственный технический \\ университет, ул. 20-летия Октября, 84, Воронеж, Россия, E-mail: dream-school@mail.ru \\ ${ }^{2}$ Старший преподаватель, Воронежский государственный технический университет, \\ ул. 20-летия Октября, 84, Воронеж, Россия, E-mail: d18sveta@mail.ru
}

\begin{abstract}
Аннотация
Растущая роль образования в современном мире объясняется глобальными тенденциями экономического и социального развития, которые государство должно учитывать при формировании своей образовательной политики, особенно в контексте создания единого европейского образовательного пространства. Поэтому сравнительный анализ образовательной политики в России и в странах Западной Европы весьма актуален, учитывая процессы формирования и развития образовательной политики в западноевропейской традиции, а также особенности российской образовательной политики на современном этапе.
\end{abstract}

Ключевые слова: образование, опыт, политика, история, общество.

\section{СПИСОК ЛИТЕРАТУРЫ}

Abramov A.M. (2002) Russian education in the XXI century: new frontiers. Moscow University Bulletin. Ser. 20. Pedagogical education. №. 2. Pp. 12-35. (in Russ).

Ashmarov I.A. (2017) Special educational needs in a university environment. Professional orientation. №. 2. Pp. 17-19. (in Russ).

Ashmarov I.A., Bobrovnikova M.A., Volkova E.A. (2016) On state policy in the field of regional education. Region: systems, economics, management. №. 2 (33). Pp. 90-97. (in Russ).

Ashmarov I.A., Ershov B.A. (2019) The role of Russian spiritual education in the formation of culture in a secular society of the XIX - early XX centuries. Border region in historical development: partnership and cooperation. Materials of the international scientific-practical conference dedicated to the 80th anniversary of the Victory of the Soviet and Mongolian troops on the Khalkhin-Gol river. Chita: Publisher: Transbaikal State University. Pp. 50-53. (in Russ).

Ashmarov I.A., Volkova E.A., Frolova E.V. (2015) On the formation of trends in the higher education system in the framework of modern globalization processes. Modern problems of science and education. №. 11. P. 975. (in Russ).

Baranova S. (2003) Legal framework for the organization of higher education in Russia. Higher education today. № 1. Pp. 74-80. (in Russ). 
Baydenko V.I. (1999) Standards in Continuing Education: Conceptual, Theoretical and Methodological Problems. M. 295 p. (in Russ).

Education development strategy: main directions. (2002) Brief Commentaries. M.: Publication of the State Duma. 63 p. (in Russ).

Ershov B., Novikov Yu.N., Voytovich D., Ermilova O., Dushkin O., Lubkin Y. (2019) Physical culture in formation of spiritual education of young people in Russia. The European Proceedings of Social \& Behavioural Sciences EpSBS. Pp. 3648-3653. (in Russ).

Ershov B.A., Nebolsin V.A., Solovieva S.R. (2020) Higher education in technical universities of Russia. 7th International conference on education and social sciences. Abstracts \& Proceedings. Pp. 55-58. (in Engl).

Ershov B.A., Perepelitsyn A., Glazkov E., Volkov I., Volkov S. (2019) Church and state in Russia: management issues. 5th International conference on advences in education and social sciences. Abstracts \& Proceedings, e-publication. Pp. 26-29. (in Engl).

Ershov B.A., Zhdanova T.A., Kashirsky S.N., Monko T. (2020) Education in the university as an important factor in the socialization of students in Russia. 6th International Conference on Advances in Education. Abstracts \& Proceedings. Pp. 517-520. (in Engl).

Galagan A.I. (2002) Integration Processes in Education: Analysis of World Trends. Social and humanitarian knowledge. №. 5. Pp. 73-85. (in Russ).

Gorev V.N., Kudryavtsev Y.A. (2002) Education in the conditions of market relations (foreign experience). M. 125 p. (in Russ).

Granichina O. A. (2006) Quality control of the educational process in universities in Russia and abroad. SPb. 211 p. (in Russ).

Kopylova A.V. (2000) Legal support and personnel policy of educational authorities of the Russian Federation. Eagle. 205 p. (in Russ).

Kozminski A. (2003) The role of higher education in reforming society in the context of globalization: academic reliability and the desire to improve the level of universities. Higher education today. № 3. Pp. 34-38. (in Russ).

Marru A.I. (2003) History of education in antiquity. M. 310 p. (in Russ).

Milner B.Z. (2003) Knowledge Management. M. 178 p. (in Russ).

Nechaev V.Ya. (2004) Parameters of Globalization and Factors of the Bologna Process. Globalization and education. The Bologna Process. Issue 2. Pp. 10 - 21. (in Russ).

Pautova V.A. (2005) History of the formation of the German higher education system. Modernization of the national higher education system and the problems of integrating Russian universities into the world educational space. Novosibirsk. Pp. 20-22. (in Russ).

Petrov V.N. (2004) Development of teacher and student mobility in the Russian educational space as a condition for entering the Bologna process. Globalization and education. The Bologna Process. Issue 2. Pp. 142-143. (in Russ).

Sharonova S.A. (2004) The Bologna Process: Civilizational Causes. Globalization and education. The Bologna Process. Issue 2. Pp. 144-146. (in Russ).

Slyusarenko I. O., Ershov B. A. (2013) Spiritual and moral education and education in the field of global problems of modernity. In the collection: Russia and the world at a new stage of global competition. materials of the International Scientific and Practical Student Conference. Pp. 247-249. (in Russ).

Sorokin P.A. (2002) Man. Civilization. Society. M. 430 p. (in Russ). 